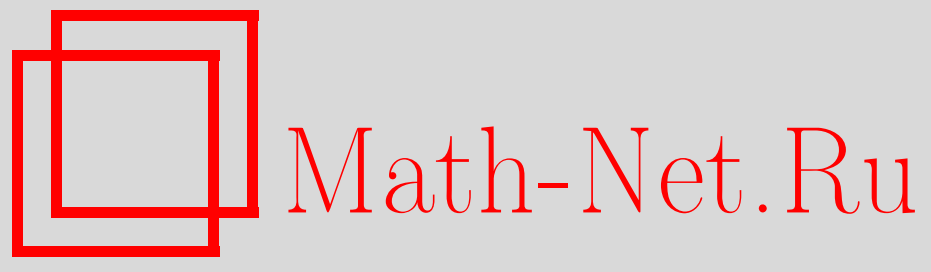

От редакторов выпуска, Матем. сб., 2016, том 207, номер 11, 3

DOI: https://doi.org/10.4213/sm8856

Использование Общероссийского математического портала Math-Net.Ru подразумевает, что вы прочитали и согласны с пользовательским соглашением http://www.mathnet.ru/rus/agreement

Параметры загрузки:

IP: 3.91 .87 .62

26 апреля 2023 г., 12:35:49

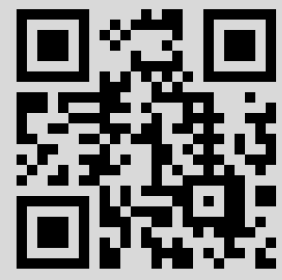




\section{ОТ РЕДАКТОРОВ ВЫПУСКА}

Настоящим выпуском продолжается серия специальных юбилейных выпусков "Математического сборника", посвященная его 150-летию. Этот выпуск тематический: в нем собраны статьи по геометрии и топологии.

Уже в первом томе "Математического сборника" были статьи по геометрии, и среди них статья К. М. Петерсона - одного из основателей российской школы геометрии "в целом". В первой половине 20-го века авторами журнала были крупнейшие геометры и топологи, в числе которых П. С. Александров, К. Борсук, Б. Н. Делоне, Д.Ф. Егоров, Н. В. Ефимов, Э. Картан, С.Э. Кон-Фоссен, К. Куратовский, Т. Леви-Чивита, С. Лефшец, Л. А. Люстерник, А. В. Погорелов, Ж. де Рам, М. Стоун, Х. Уитни, П. С. Урысон, П. Хегор, Х. Хопф, Э. Чех, С. Эйленберг.

На страницах "Математического сборника" были опубликованы фундаментальные результаты, ставшие классическими и сыгравшие ключевую роль в создании и развитии современных геометрии и топологии, в том числе:

- знаменитая теорема А.А. Маркова о движениях, сохраняющих класс эквивалентности зацепления, получающегося при замыкании косы (1(43):1 (1936), 73-78),

- построение А. Н. Колмогоровым умножения в когомологиях топологического пространства (1(43):5 (1936), 701-706),

- доказательство А.Д. Александровым существования выпуклого многогранника с заданной внутренней метрикой поверхности (11(53):1-2 (1942), 15-65),

- построение Л.С. Понтрягиным характеристических классов гладких многообразий, названных впоследствии классами Понтрягина (21(63):2 (1947), 233-284; 24(66):2 (1949), 129-162),

- построение Л.В. Келдыш примера открытого и монотонного отображения трехмерного куба на куб любой большей размерности (41(83):2 (1957), 129-158; 43(85):2 (1957), 187-226),

- вычисление С. П. Новиковым кольца унитарных кобордизмов (57(99):4 (1962), 407-442),

- доказательство А. В. Чернавским локальной стягиваемости группы гомеоморфизмов евклидова пространства (79(121):3(7) (1969), 307-356).

И в настоящее время ведущие геометры и топологи публикуют свои результаты в журнале "Математический сборник".

В. М. Бухштабер

А. А. Гайфуллин

С. П. Новиков 